\title{
LC-ESI-MS/GC-MS Based Metabolite Profiling of Chlorophytum comosum (Thunb.) Jaques and evaluation of its antioxidant and antiproliferative effects on lung and breast cancer cell lines
}

\section{SHEHLA ADHAMI \\ Jamia Hamdard}

Humaira Farooqi ( $\sim$ hfarooqi@jamiahamdard.ac.in )

Jamia Hamdard https://orcid.org/0000-0002-8222-7705

MALIK ZAINUL ABDIN

Jamia Hamdard

RAM PRASAD

University of Alabama at Birmingham School of Optometry

ASRAR AHMAD MALIK

Jamia Hamdard

\section{Research}

Keywords: GC-MS, LC-ESI-MS, Chlorophytum comosum, A549, MCF-7, 56 Phytochemicals, Cytotoxicity

Posted Date: May 22nd, 2020

DOI: https://doi.org/10.21203/rs.3.rs-29686/v1

License: (c) (i) This work is licensed under a Creative Commons Attribution 4.0 International License.

Read Full License 
1 LC-ESI-MS/GC-MS Based Metabolite Profiling of Chlorophytum comosum

2 (Thunb.) Jaques and evaluation of its antioxidant and antiproliferative effects on

3 lung and breast cancer cell lines

4 Shehla Adhami ${ }^{a}$, Humaira Farooqi ${ }^{\mathrm{a}, *}$, Malik Zainul Abdin ${ }^{\mathrm{a}}$, Ram Prasad $^{\mathrm{b}}$ and Asrar

$5 \quad$ Ahmad Malik ${ }^{\mathrm{a}}$

6 a Department of Biotechnology, School of Chemical and Life Sciences, Jamia Hamdard,

7 New Delhi-110062, India.

$8^{\text {b }}$ Department of Ophthalmology and Visual Sciences, University of Alabama at

9 Birmingham, Birmingham, AL-35294, USA

10

$11 *$ Corresponding Author:

12 Humaira Farooqi (M.S. Ph.D.), Assistant Professor,

13 Department of Biotechnology, School of Chemical and Life Sciences,

14 Jamia Hamdard, New Delhi, 110062, India.

15 E mail: hfarooqi@jamiahamdard.ac.in

16 ORCID id: https://orcid.org/0000-0002-8222-7705

17 Contact no: 011-26059688

18

19

20

21

22

23

24

25 
LC-ESI-MS/GC-MS Based Metabolite Profiling of Chlorophytum comosum

27 (Thunb.) Jaques and evaluation of its antioxidant and antiproliferative effects on lung and breast cancer cell lines

Abstract

Background Chlorophytum comosum popularly known as Spider Ivy is an important medicinal plant in traditional Chinese medicine utilized in the treatment of many ailments, however its detailed chemical composition and biological activity is not much explored. The present study aims to identify different chemical constituents present in roots and leaves of Chlorophytum comosum and investigates its antioxidant, antiproliferative and haemolytic effects on breast (MCF-7) and lung cancer cell lines (A549, H1299) as compared to normal lung (L-132) cell lines.

Methods Chemical constituents from aqueous roots and leaves extracts were identified using LC-ESI-MS/GC-MS. The identified compounds were annotated based on match of mass spectral database with the literature using NIST 14 and METLIN databases. Antioxidant activity was checked using DPPH, FRAP and TPC assays. The antiproliferative effects of ethanolic roots and leaf extracts of Chlorophytum comosum were measured by MTT assay on breast (MCF-7), lung cancer (A549 \& H1299) and normal lung (L-132) cell lines. The toxicity studies of the extracts were carried out using Haemolytic assay.

Results GC-MS analysis identified 34 new metabolites in roots and 17 from leaves, while as 17 compounds from roots and 7 from leaves were detected by LC-ESI-MS. Significant antiproliferative effects were observed on MCF-7 \& A549 cell lines with $\mathrm{IC}_{50}$ values ranging from $31.94 \mu \mathrm{g} / \mathrm{ml}$ to $77.84 \mu \mathrm{g} / \mathrm{ml}$ while no marked response was observed against normal cell line. Haemolysis studies revealed no significant toxicity of the extracts

50 towards the biological system. 
51 Conclusion Our study is the first preliminary report on the detailed chemical composition and antiproliferative potential of Chlorophytum comosum, indicating significant specific antiproliferative activities against lung (A549) and breast (MCF-7) cancer cell lines. However, further studies are required to understand the mechanism involved in cytotoxic properties of Chlorophytum comosum.

56 Keywords: GC-MS, LC-ESI-MS, Chlorophytum comosum, A549, MCF-7, Phytochemicals, Cytotoxicity.

\section{Background}

Chlorophytum comosum (Thunb.) Jacques commonly known as Spider Ivy belongs to

60 family Lilliaceae and genus Chlorophytum. It is a popular ornamental plant and is 61 considered to be an excellent air purifier and air detoxifier [1-2]. In traditional Chinese

62 medicine, it is used for the treatment of respiratory ailments such as Bronchitis, Asthma [3-4], Fractures and Burns [3]. Saponins isolated from roots of Chlorophytum comosum have been found to exhibit cytotoxic and antitumour promoter activity in selected cancer cell lines [5-6].However the detailed information on plant phyto-composition is still lacking. Despite having the ethnobotanical background validated by previous findings, not many efforts have been taken to explore this plant for its therapeutic active constituents. In this study we reported for the first time the comparative and comprehensive chemical profiling of Chlorophytum comosum through GC/MS, LC-ESIMS method and evaluated their antioxidant and antiproliferative potential using in vitro assays. The newer compounds identified were matched using mass spectral database search by NIST and METLIN [7] .The antiproliferative activity of ethanolic roots (CCRE) and leaf (CCLE) extracts were checked by MTT assay on breast (MCF-7) and lung (A549 \& H1299) and normal lung cell line (L-132). 


\section{Plant Material}

Plant material was obtained from the herbal garden of Jamia Hamdard. The harvested roots and leaves were fully mature, healthy and free from disease. The plant samples were identified by the botanist Dr. Sunita Garg (NISCAIR, New Delhi) and the voucher specimens bearing no. NISCAIR/RHMD/CONSULT/ 2016/2975-02 were deposited in the herbarium.

\section{Chemicals and Reagents}

84 All the solvents used for the study i.e. Methanol, n-Butanol, Petroleum Ether, Water,

85 Formic Acid, Acetonitrile were of HPLC/LC-MS grade and were purchased from Merck 86 (Darmstadt, Germany). Ethanol and chemicals (DPPH, TPTZ, L- Ascorbic acid, $\mathrm{FeCl}_{3}$, 87 and $\mathrm{Na}_{2} \mathrm{CO}_{3}$ ) were of the highest purity and were purchased from the local commercial supplies. Cell culture media DMEM with phenol red (\#1932403), Fetal Bovine Serum (\# 10438034), Trypsin -EDTA solution with phenol red (\#1897336) and antibiotic solution

90 PenStrep (\#192493) were purchased from Gibco USA. MTT reagent (\#MICB8173V),

91 Standard Vinblastine, Folin Ciocalteau reagent were obtained from Sigma Aldrich USA.

92 Hydrogen peroxide, Gallic acid and DMSO were purchased from Thomas Baker India. All

93 the cell lines used in the study were procured from ATCC (USA).

\section{Preparation of Plant Extracts}

95 Chlorophytum comosum leaves aqueous (CCLA), ethanolic (CCLE) and Chlorophytum

96 comosum roots aqueous (CCRA), ethanolic fractions (CCRE) were prepared using soxhlet

97 extraction method. Briefly, the plant materials were washed to remove debris, air-dried and

98 grinded. The grinded plant material $(10 \mathrm{gm})$ was defatted using petroleum ether $(1: 15 \mathrm{w} / \mathrm{v})$,

99 suspended in water/ethanol $(150 \mathrm{~mL})$ and extracted for $24 \mathrm{hrs}$ at $50^{\circ} \mathrm{C}$. The extracts were 100 then collected, filtered, and processed to become colourless using n-butanol, concentrated 
101 on a rotary evaporator at $55^{\circ} \mathrm{C}$ and $55 \mathrm{mbar}$ pressure until the semi-dried substance was

102 obtained. The semi-dried substance was further lyophilized to remove the traces of solvent.

103 The samples were then stored in airtight vials at $4^{0} \mathrm{C}$ till further use.

104 Gas Chromatography/Mass Spectrometry (GC-MS) Analysis

105 To conduct the GC-MS analysis, aqueous leaf and root extracts (5 mg each) were dissolved 106 in $1 \mathrm{~mL}$ of methanol and filtered using 0.22 -micron filter to utilize in further analytical

107 procedures. GC-MS analysis was carried out on Shimadzu GCMS QP-2010 plus system

108 using chromatographic separation column (Rtx-5 Sil MS column; $30 \mathrm{~m} \times 0.32 \mathrm{~mm}$ id $109 \times 0.25 \mu \mathrm{m}$ film thickness). The operating conditions of the column included oven

110 temperature program from $80^{\circ} \mathrm{C}$ to $210^{\circ} \mathrm{C}$ at $4^{\circ} \mathrm{C} / \mathrm{min}$ withhold time of $2 \mathrm{~min}$ and from

$111210^{\circ} \mathrm{C}$ to $300^{\circ} \mathrm{C}$ at $15^{\circ} \mathrm{C} / \mathrm{min}$ withhold time of $5 \mathrm{~min}$, and the final temperature was kept

112 for $20 \mathrm{~min}$. The injector temperature was maintained at $270^{\circ} \mathrm{C}$, the volume of injected

113 sample was $0.3 \mu \mathrm{L}$, pressure $85.4 \mathrm{kPa}$, total flow $76.8 \mathrm{~mL} / \mathrm{min}$, column flow $1.21 \mathrm{~mL} / \mathrm{min}$,

114 linear velocity $40.5 \mathrm{~cm} / \mathrm{sec}$, purge flow $3.0 \mathrm{~mL} / \mathrm{min}$, split ratio: 60.0 , ion source

115 temperature $230^{\circ} \mathrm{C}$, scan mass range of $\mathrm{m} / \mathrm{z} 40-600$ and interface line temperature $280^{\circ} \mathrm{C}$.

116 The peak area based on retention time was expressed as percentage composition of the

117 crude extract. The identification and characterization of compounds were performed by

118 comparing their mass spectra with data from NIST 14 (National Institute of Standards and

119 Technology, US) and WILEY 8 library.

120 Liquid Chromatography Mass Spectrometry (LC-ESI-MS) analysis in positive ion

121 mode

122 LC-MS is the high-end technology which is increasingly employed in plant analytical

123 research [7]. LC-MS enables the separation, identification and characterization of

124 phytoconstituents present in complex crude plant extracts by giving high chemical

125 specificity and sensitivity. Qualitative or quantitative estimation of known/unknown 
126 compounds present in the crude mixture can be deciphered using LC-MS [7]. Briefly

127 aqueous extracts CCLA and CCRA were prepared in LCMS grade methanol and analysed

128 on QSM-LC-MS electrospray ionization (ESI) single quadrupole mass spectrometer

129 (Waters, Milford-MA) coupled with Synapt G2 using BEH C18, 1.7 $\mu \mathrm{m}-2.1$ x 50 mm

130 column on positive ion mode (ES+) with following mobile phases: (A) $0.1 \%$ formic acid

131 (B) Acetonitrile (C) Methanol (sample input and acquisition; $5 \mu \mathrm{L} / \mathrm{min}$ flow rate and 250

$132 \mu \mathrm{L}$ injection volume). The parameters for analysis were as follows: source temperature

$1331000^{\circ} \mathrm{C}$, cone voltage $40 \mathrm{eV}$, capillary voltage $3 \mathrm{kV}$, desolvation temperature $3500^{\circ} \mathrm{C}$, cone

134 gas flow $50 \mathrm{l} / \mathrm{h}$, and desolvation gas flow $900 \mathrm{l} / \mathrm{h}$. Mass spectra were detected in the ESI

135 positive ion mode between $\mathrm{m} / \mathrm{z}$ 100-1000 with a scan time of $0.40 / \mathrm{sec}$ for 20 minutes.

136 Leucine Enkephalin was used as a reference material for mass spectrometer tuning and

137 calibration. The data generated by LC-ESI-MS was analysed using an open source platform

138 XCMS software combined with METLIN [8].

\section{DPPH Free Radical Scavenging Activity}

140 The free radical scavenging activity of Chlorophytum comosum aqueous leaf (CCLA) and

141 roots extract (CCRA) were measured following methodology given by [9] with slight 142 modifications. Briefly, $200 \mathrm{mmol} \mathrm{L}^{-1}$ of DPPH solution was prepared by dissolving $1.57 \mathrm{~g}$ 143 of DPPH in $20 \mathrm{~mL}$ of methanol and was stored in dark. Different concentrations (1000 $144 \mu \mathrm{g} / \mathrm{mL}-62.5 \mu \mathrm{g} / \mathrm{mL}$ ) were prepared separately on a 96 wells microplate by serial dilution 145 (Stock conc. $100 \mathrm{mg} / \mathrm{mL}$, working conc. $1 \mathrm{mg} / \mathrm{mL}$ ). Blank was prepared using methanol. 146 Control was prepared by adding $200 \mu \mathrm{L}$ of DPPH in $50 \mu \mathrm{L}$ of water. The reaction was 147 initiated by adding $200 \mu \mathrm{L}$ of DPPH in $50 \mu \mathrm{L}$ of the extract of varied concentrations followed 148 by an incubation period of 60 minutes. The absorbance was recorded on ELISA microplate 149 reader at $515 \mathrm{~nm}$. Ascorbic acid was taken as standard and tested with the same 150 concentrations as extracts. The experiments were repeated 3 times and \% DPPH free radical 
151 scavenging activity of the extracts was measured using the following formula and values

152 were expressed as mean $\pm \mathrm{SD}$.

\section{Ferric Reducing Antioxidant Power Assay (FRAP)}

158 FRAP is an electron transfer based assay which monitors the reaction of $\mathrm{Fe}^{2+}$ with TPTZ to

159 form a violet-blue color from colorless oxidized $\mathrm{Fe}^{3+}$. The reducing ability of the extracts

160 were measured by the method given by [10] with some modifications. Briefly different

161 concentrations of the extracts were prepared by serial dilution $(1000 \mu \mathrm{g} / \mathrm{mL}$ to $62.5 \mu \mathrm{g} / \mathrm{mL})$

162 on 96 wells microplate (Stock conc. $100 \mathrm{mg} / \mathrm{mL}$, working conc. $1 \mathrm{mg} / \mathrm{mL}$ ). The standard

163 curve was prepared using Ascorbic acid. FRAP working solution was prepared by adding

16410 volume of acetate buffer $(300 \mathrm{mM}, \mathrm{pH}-3.6,20 \mathrm{~mL})$ with 1 volume of TPTZ (40mM

165 prepared in dil. HCL, 2mL) and 1 volume of $\mathrm{FeCl}_{3}(20 \mathrm{mM}, 2 \mathrm{~mL})$ solution. The reaction

166 mixture were mixed well and stored at $37^{\circ} \mathrm{C}$. Deionized milli q water served as blank while

167 control contained FRAP solution alone. $50 \mu \mathrm{L}$ of the extract were mixed with $240 \mu \mathrm{L}$ of

168 FRAP solution on 96 well microplate and incubated in dark for 30 minutes. The absorbance

169 was measured at $593 \mathrm{~nm}$. FRAP values were obtained by comparing the absorption change

170 in test mixture (triplicate values) with the standard.

\section{Determination of Total Phenolic Contents (TPCs)}

172 Total phenolic contents of the aqueous extracts were measured as described by [9] with 173 slight modifications. Folin Ciocalteau (FC) reagent was diluted in 1:1 ratio (v/v) in double 174 distilled water (DDW). $25 \mu \mathrm{L}$ of each sample (stock conc. $100 \mathrm{mg} / \mathrm{mL}$ ) was loaded on to 175 the 96 well plate and diluted 4 times by adding $75 \mu \mathrm{L}$ of DDW. To the diluted samples, 
$17625 \mu \mathrm{L}$ of the FC reagent was added and incubated for $6 \mathrm{~min}$, then $100 \mu \mathrm{L}$ of $75 \mathrm{~g} \mathrm{~L}^{-1}$

$177 \mathrm{Na}_{2} \mathrm{CO}_{3}$ was added. The solution was placed in the dark for $30 \mathrm{~min}$ at room temperature

178 for color development. After incubation the absorbance were taken at $765 \mathrm{~nm}$. Acetone

179 served as blank. Gallic acid was used as a standard $(1000 \mu \mathrm{g} / \mathrm{mL}-62.5 \mu \mathrm{g} / \mathrm{mL})$ to produce

180 a calibration curve (average $\mathrm{R}^{2}=0.9990$ ). Each sample was run in duplicate. Total

181 phenolic concentration was expressed as $\mathrm{mg}$ gallic acid equivalent (GAE) $\mathrm{g}^{-1}$ dried 182 sample.

\section{MTT Assay}

184 The antiproliferative effects of ethanolic roots (CCRE) and leaf extracts (CCRE) were 185 measured using MTT assay. The cytotoxic effect of CCLE and CCRE on MCF-7(Breast) 186 and A549, H1299 (Lung) cancer cell lines were investigated and compared against normal 187 human epithelial cell line (L-132) for the selective response. Cell lines were procured from 188 ATCC, USA and were maintained at $37^{\circ} \mathrm{C}$ with $5 \% \mathrm{CO}_{2}$ in an incubator using DMEM 189 complete medium with $10 \%$ FBS and $1 \%$ antibiotic solution. Briefly, cells were seeded with 190 a cell density of 40,000 cells per well into 96 well culture plate. Cells were treated with 191 varying extract concentrations $(10-320 \mu \mathrm{g} / \mathrm{mL})$ for $24 \mathrm{hrs}$. Vinblastine was used as positive 192 control in the study and was exposed to cells at varying concentrations from 3.12-100 $\mu \mathrm{M}$. 193 After $24 \mathrm{hrs}$ of the treatment, cells were treated with $10 \mu \mathrm{L}$ MTT solution $(0.5 \mathrm{mg} / \mathrm{mL})$ and 194 further incubated for $4 \mathrm{hrs}$, the medium was then discarded and the formazan crystals were 195 dissolved using $100 \mu \mathrm{l}$ of DMSO solution. The absorbance was measured at 570nm using 196 Spectra max spectrophotometer. The \% cell inhibition were measured by using the following 197 formula (Eq.-2). The concentration at which the test drug inhibited cell growth by $50 \%$ i.e. 198 inhibitory concentration $\left(\mathrm{IC}_{50}\right)$, is generated from the dose-response curves using Graph Pad 199 Prism software (8.1). The final concentration of DMSO was maintained at $0.1 \%$ in all the 200 test preparations. $1 \%$ DMSO containing cells served as vehicle control. 


\section{Haemolysis Assay}

204 The haemolytic activity of the extracts was measured by colorimetric assay as described 205 previously by [11] at $594 \mathrm{~nm}$. Briefly, $5 \mathrm{~mL}$ of fresh human blood was collected in $\mathrm{K}_{3}$ EDTA 206 vacutainer tubes and was centrifuged at $1000 \mathrm{rpm}$ for $10 \mathrm{~min}$ at $4^{\circ} \mathrm{C}$. The supernatant 207 containing plasma was carefully removed and the white buffy layer was aspirated with 208 precautions and discarded into $3 \%$ hydrogen peroxide solution. The erythrocytes were then 209 washed thrice with 1 X PBS, pH 7.4. Washed erythrocytes were diluted twice (1:2) with $1 \mathrm{X}$ 210 PBS. $50 \mu \mathrm{L}$ of the diluted erythrocytes suspension were taken into $2 \mathrm{~mL}$ Eppendorf tube and $211100 \mu \mathrm{L}$ of ethanolic root and leaves extract of different concentrations ranging from 10 $212 \mu \mathrm{g} / \mathrm{mL}-320 \mu \mathrm{g} / \mathrm{mL}$ were added. $100 \mu \mathrm{L}$ of $1 \mathrm{X}$ PBS was used as negative control while 100 $213 \mu \mathrm{L}$ of $1 \%$ SDS served as positive control The reaction mixture was incubated at $37^{0} \mathrm{C}$ for $21460 \mathrm{~min}$. After incubation the volume was made upto $1 \mathrm{~mL}$ by adding $850 \mu \mathrm{L}$ of $1 \mathrm{X}$ PBS. 215 Finally centrifuged at $300 \mathrm{rpm}$ for $3 \mathrm{~min}$ and the resulting haemoglobin in supernatant was 216 measured at $540 \mathrm{~nm}$ by spectrophotometer to determine the concentration of haemoglobin.

217 The percent haemolytic activity of the extracts were expressed using (Eq.-3).

$$
\mathrm{S}=\text { Absorbance of samples. }
$$

\section{Statistical Analysis}

$222 \mathrm{IC}_{50}$ values for cytotoxicity tests were derived from nonlinear regression analysis (curve 223 fit) based on sigmoid dose-response curve (variable) and computed using Graph Pad Prism

2248.1 (San Diego, CA, USA). The data were expressed as mean \pm SD of three independent 225 experiments. Differences were considered statistically significant at $\mathrm{p}<0.05$. 


\section{Results}

\section{Metabolite profiling of leaf and roots of Chlorophytum comosum by GC-MS}

228 The qualitative and quantitative analysis of the active constituents present in aqueous roots

229 and leaf extracts of Chlorophytum comosum were performed using GC/MS. Thirty four 230 new compounds were identified in leaf extracts (CCLA) while 17 metabolites were 231 observed in root extracts (CCRA). The identified phytoconstituents belonged to different 232 classes of phenols, triterpenes, sterols, alcohols, aldehydes, fatty acids, saponins, organic 233 acids and hydrocarbons. Significant differences in chemical composition between roots 234 and leaf extracts were observed. Phenolic compounds such as Guaiacol (1.38\%), 4235 vinylguaiacol (1.28\%), Syringol (1.08\%), and 3-hydroybenzyl alcohol (7.59\%) were 236 observed in the leaf extract (Table 1). On the contrary the saponins of various class such 237 as Tigogenin tosylate $(4.43 \%)$, Neotigogenin $(16.25 \%)$, Yuccagenone $(14.05 \%)$ were 238 found as the major portion of the root part (Table 2). However, saponins like 239 Sarsasapogenin (7.54\%) and Diosgenin (1.27\%) were detected in leaf as well. An 240 important plant sterol $\beta$ - Sitosterol was found to be present in higher amounts in roots $241(7.79 \%)$ as compared to leaf (1.24\%). Similarly, the fatty acids were also present in higher

242 amounts in roots as compared to leaves. Polysaccharides were also identified in leaf but 243 found to be absent in roots. The \% content of metabolites was expressed in terms of peak 244 area depending upon retention time. Identification of the components was achieved based 245 on the retention indices match and fragmentation pattern with the database available in 246 NIST14 library.

247 Metabolite profiling of leaf and roots of Chlorophytum comosum by LC-ESI-MS in 248 positive ion mode

249 LC-ESI-MS analysis of CCLA and CCRA extracts led to the tentative identification of 250 compounds detected in positive ion mode using METLIN database batch search with an 
accuracy of 10ppm. The identified compounds were annotated based on match of mass spectral database with the literature and were selected from the database based on possibility of availability and solubility in crude mixture. 17 metabolites were detected in roots among which Purpurogallin [12], Ginsenoyne B [13], Sagecoumarin [14] Gnidicin [15] possess important pharmacological functions. In leaf 7 metabolites annotated, were fatty acids like Oleyl Anilide a known ACAT inhibitor [16] , 6-Bromo-5E,9Z,13Zdocosatrienoic acid, 3-(2-Heptenyloxy)-2-hydroxypropyl undecanoate, 5,6-Dichloro-1,3cyclohexadiene, alkaloid Serratanidine, Salicylic acid beta-D-glucoside and Methyl (9Z)6'-oxo-6,5'-diapo-6-carotenoate. The peak pattern of metabolites separated in positive ion mode $[\mathrm{M}+\mathrm{H}]$ in roots and leaves are depicted in Table (3 \& 4). LC-ESI-MS total

261 chromatogram is presented in (Figure 1).

\section{Antioxidant activity by Chlorophytum comosum}

Antioxidants have been found to be a stabilizing factor in cancer prevention [17]. In the present study the antioxidant potential of Chlorophytum comosum aqueous extracts (CCLA \& CCRA) were determined by DPPH and FRAP assay. The scavenging effects were checked on 5 different concentrations $(62.5-1000 \mu \mathrm{g} / \mathrm{ml})$. Leaf extract exhibited maximum response in both DPPH assay $\left(\mathrm{IC}_{50} 3.08 \mu \mathrm{g} / \mathrm{ml}\right)$ and FRAP $(311.2 \mu \mathrm{g} / \mathrm{ml})$ assay as compared to root extracts $\mathrm{IC}_{50} 5.8 \mu \mathrm{g} / \mathrm{ml}$ in DPPH \& $548.3 \mu \mathrm{g} / \mathrm{ml}$ in FRAP). $\%$ scavenging of DPPH followed a dose dependent increase with slighter variation at 125 $\mu \mathrm{g} / \mathrm{ml}$, similar response were observed in FRAP assay where the absorbance indicating the reducing ability of the extracts increased dose dependently (Figure $2 \mathrm{a}$ and $2 \mathrm{~b}$ ).

\section{Quantification of total phenolic contents (TPCs)}

273 In agreement with our GC-MS finding the total phenolic content in the leaf extract were

274 found to be higher than the root extract The total phenolic content of roots and leaf extract 275 was found to be 2.0 .2 and $3.38 \mathrm{mg} / \mathrm{g}$ respectively of the gallic acid equivalent (GAE) $\mathrm{g}^{-1}$ 
276 dried sample (Figure 2c) Each sample was run in duplicates. The standard curve was

277 calibrated using 5 different concentrations $(62.5-1000 \mu \mathrm{g} / \mathrm{ml})$ and the spectra was 278 recorded at $795 \mathrm{~nm}$.

\section{Anti-proliferative activity on breast cancer cell lines (MCF-7)}

280 The anti-proliferative potential of ethanolic leaf (CCLE) and roots (CCRE) extracts on 281 MCF-7 cancer cells versus L-132 normal cells were determined by MTT assay. Cells 282 were treated with the extracts (CCLE, CCRE) in dose dependent manner $(10 \mu \mathrm{g} / \mathrm{ml}-$ $283320 \mu \mathrm{g} / \mathrm{ml}$ ) for 24 hours. The $\%$ cell inhibition of MCF-7 cells was observed from $8.62 \%$ 284 to $91.2 \%$ in roots (CCRE) while in leaves (CCLE) it was observed from $3.45 \%$ to 88.45 $285 \%$. The cytotoxic effect of the CCRE was higher as compared to the CCLE extract with 286 an $\mathrm{IC}_{50}$ value of $31.94 \mu \mathrm{g} / \mathrm{mL}$, while as for the CCLE it was $57.8 \mu \mathrm{g} / \mathrm{mL}$ (Figure 3). Most 287 importantly at the similar doses, these extracts did not show significant reduction on the viability of L-132 cells thereby suggesting that their cytotoxicity is specific towards cancer cells. The $\mathrm{IC}_{50}$ value ranges were in accordance with NCI guidelines where the suitability of a drug candidate with less than $100 \mu \mathrm{g} / \mathrm{ml}$ is taken into consideration.

291 Standard vinblastine exhibited the similar level of inhibitory effects with $\mathrm{IC}_{50}$ value of 6.9

$292 \mu \mathrm{M}$ in MCF-7 and $80.1 \mu \mathrm{M}$ in L-132 cell lines as shown in (Figure 3).

\section{Anti-proliferative activity on lung cancer cell lines (A549 \& H1299)}

294 In response to 24 hrs dose dependent treatment of ethanolic leaf and root extracts on lung 295 cancer cell lines, significant cytotoxicity with varying response on each cell line was 296 observed. In A549 cell line, dose dependent \% cell inhibition was observed from $9.32 \%$ 297 to $92.7 \%$ (CCRE) while as, in CCLE it dropped from $8.32 \%$ to $91.7 \%$ with an $\mathrm{IC}_{50}$ 298 values of $62.25 \mu \mathrm{g} / \mathrm{mL}$ and $77.84 \mu \mathrm{g} / \mathrm{mL}$ respectively. In case of $\mathrm{H} 1299$ no significant 299 anti-proliferative effects of roots extract was seen as the maximum \% cell inhibition 300 achieved was from $4.32 \%$ to $58.14 \%$ while on the other hand \% cell inhibitory trend of 
$3019.17 \%$ to $90.68 \%$ was observed in leaves extract. Among both the cell lines A549 cell

302 line showed maximum response with an $\mathrm{IC}_{50}$ value of $62.25 \mu \mathrm{g} / \mathrm{mL}$ (CCRE) and 77.84

$303 \mu \mathrm{g} / \mathrm{mL}$ (CCLE) as compared to $\mathrm{H} 1299$ where the calculated $\mathrm{IC}_{50}$ values were $173.7 \mu \mathrm{g} / \mathrm{mL}$

304 (CCRE) and $82.63 \mu \mathrm{g} / \mathrm{mL}$ (CCLE). No inhibitory response was seen on L-132.Selective

305 response of the extracts on different cancer cell lines based on $\mathrm{IC}_{50}$ values are depicted in

306 (Figure 3).

307 In vitro haemolytic effects of Chlorophytum comosum on human erythrocytes

308 The haemolysis of red blood cells (RBCs) is a major concern for the clinical development

309 of therapeutic agents [18]. Therefore to determine the safety profile, the haemolytic

310 activities of the CCRE and CCLE were also evaluated. The haemolytic activity of the

311 extracts were found to be insignificant and did not raise beyond $30 \%$ at the selected

312 concentrations however the \% haemolytic activity was observed in dose dependent

313 manner. This indicates that even at maximum inhibitory concentration, the samples

314 CCLE and CCRE did not show any significant haemolytic activity on RBC's thus CCLE

315 and CCRE can be considered safe for pharmaceutical studies. Percent (\%) haemolytic

316 active at different concentrations of CCRE and CCLE is depicted in (Table 5).

\section{Discussion}

318 Chlorphytum comosum (Thunb). Jacques (Spider Ivy) is a well-known plant for its

319 ornamental value worldwide however based on ethanopharmacological evidence it has

320 documented to be used in traditional Chinese medicine preparations for treatment of

321 respiratory ailments, fracture and burns [3-4] In India roots part of Chlorophytum

322 comosum is available under the common name of 'Safed Musli' and is believed to be

323 utilized as a substitute/ adulterant in preparation of important class of drug 'Rasayna' in

324 Ayurveda [19]. Even though earlier studies have isolated few steroidal saponins from root

325 extracts of Chlorophytum comosum that have found to possess anti-tumor cytotoxic 
326 properties [5-6], not much attempts were made further to investigate this plant for its

327 pharmaceutical potential. With reference to the previous studies and based on 328 ethanomedical uses specifically with respect to its role in treatment of respiratory ailments 329 ,we decided to perform the comprehensive chemical profiling of various parts of 330 Chlorophytum comosum and revealed the significant antiproliferative activity of 331 ethanolic roots and leaves extracts of Chlorophytum comosum against the cancer cells 332 lines of two different origin i.e. Lung (A549, H1299) and Breast (MCF-7). Our study also 333 noted that the selective and specific response of the crude extracts were towards cancer 334 cell lines as no cell inhibitory effects were seen on normal Lung (L-132) cell line when 335 tested comparatively. The maximum antiproliferative effects with high selectivity were 336 seen on MCF-7 and A549 cell lines with $\mathrm{IC}_{50}$ values $<100 \mu \mathrm{g} / \mathrm{ml}$ (Figure 3). In case of 337 H1299 cell line no significant antiproliferation was recorded in roots extracts $\left(\mathrm{IC}_{50}\right.$ value> $338100 \mu \mathrm{g} / \mathrm{ml}$ ) however leaves extract showed moderate activity towards H1299 cell line $339\left(\mathrm{IC}_{50}\right.$ value $\left.=82.63 \mu \mathrm{g} / \mathrm{ml}\right)$. These results are in accordance of the previous studies where 340 Butanolic root fractions of Chlorophytum comosum yielded significant anti-tumor 341 promoter activity against tumor promoter induced phospholipids metabolism of HeLa cell

342 lines[5] In another study conducted by Matushita et al., apoptosis induction by Butanolic extracts in four human cancer cell lines (HeLa, CCRF-HSB-2,HL-60 and U937) were seen [4]. Chinese herbs are the excellent source of bioactive natural products that have 345 been found to inhibit proliferation, induce apoptosis, suppress angiogenesis, retard 346 metastasis and enhance chemotherapy, exhibiting anti-cancer potential both in vitro and 347 in vivo [20]. To discover new potential sources of anticancer plants, initial in vitro 348 cytotoxic screening and chemical profiling of the plant is an important step and provides 349 basic evidence of availability of active metabolites which needs to be further validated by 350 isolation and characterization studies followed by in vivo screening. Our study provides 
351 the initial data for the selection of this plant for its consideration towards the isolation of

352 novel anticancer compounds.

353 Saponins are the known cytotoxic agents and possess strong haemolytic activity [21].GC-

354 MS findings from our studies revealed saponins as major constituents in roots portion

355 while phenols were mainly found to be present in leaves extracts. To rule out the

356 possibility of toxic effects of the extracts, we measured the anti-haemolytic activity of the

357 extracts using haemolysis assay. No significant haemolytic studies were observed in both

358 leaves and roots extract which may suggest the possibility of mechanism of action of

359 these phytoconstituents at the synergistic level. Similarly high phenolic content of leaves

360 extract as indicated by GC-MS and TPC measurement might have been responsible for

361 the better antioxidant effects in leaves extract as compared to root extracts. In a study

362 conducted by Deore et al. methanolic roots extract possessed the strongest antioxidant

363 activity among various species of Chlorophytum [22]. A plethora of evidences supports

364 phenolic components as a strong antioxidant and anticancer agents [23-24]. Compounds

365 like Purpurogallin as recorded in LC-MS data is a suggested anticancer compound which

366 inhibits mitogen-activated protein kinase kinase 1/2 (MEK1/2) signaling

367 pathway[25].Thus, to best of our knowledge our study is the first systematic and

368 comparative profiling of the plant marking the presence of other anticancer active

369 molecules than saponins, however this is the initial screening which needs to be further

370 validated by isolation and characterization studies to find out the lead molecules involved

371 in anticancer therapy.

\section{Conclusion}

373 We conclude that Chlorophytum comosum possess diversified active constituents of

374 therapeutic potential (chiefly phenols and saponins) that in synergy possess significant

375 antioxidant and antiproliferative potential against the breast (MCF-7) and lung cancer (A- 
376 549) cell lines. Our study also justifies the traditional use of Chlorophytum comosum in

377 treatment of lung associated disorders.

$378 \quad$ List of Abbreviations

379 CCLA : $\quad$ Chlorophytum comosum leaf aqueous extract

380 CCRA : $\quad$ Chlorophytum comosum roots aqueous extract

381 CCLE : $\quad$ Chlorophytum comosum leaf ethanolic extract

382 CCRE : Chlorophytum comosum roots ethanolic extract

383 TPCs : Total Phenolic Contents

384 DPPH : 2, 2-diphenyl-1-picrylhydrazyl

385 FRAP : $\quad$ Ferric Reducing Antioxidant Power

386 GC-MS: Gas Chromatography Mass Spectrometry

387 LC-ESI-MS: Electrospray Ionization Mass Spectrometry

388 Declaration

389 Ethics Approval and Consent to Participate

390 Not Applicable

391 Consent for Publication

392 Not Applicable

393 Availability of Data and Materials

394 All data generated or analysed during this study are included in this published article [and

395 its supplementary information files].

396 Competing Interests

397 "The authors declare that they have no competing interests"

398 Author's Contribution

399 The study conceptualization and design was done by Farooqi H. The experiment

400 execution, data collection, data analysis and manuscript drafting was completed by 
401 Adhami S, Abdin M.Z. provided the necessary facilities for the study and Malik A.A.

402 provided with the suggestions for improved manuscript.

\section{Acknowledgment}

404 The authors are thankful to JNU and AIRF facilities for technical assistance to perform

405 GC-MS /LC-ESI-MS analysis. A special thanks to Mr. Hashmat, the maintainer of herbal 406 garden Jamia Hamdard. The fellowship granted by Hamdard National Foundation is 407 highly appreciated.

\section{References}

409 1. Giese M, Bauer-Doranth U, Langebartels C, Sandermann Jr H. Detoxification of 410 Formaldehyde by the Spider Plant (Chlorophytum comosum L.) and by Soybean (Glycine 411 max L.) Cell-Suspension Cultures. Plant Physiol. 1994,104(4):1301-1309.

412 2. Gawrońska H, Bakera B. Phytoremediation of particulate matter from indoor air by 413 Chlorophytum comosum L. plants. Air Qual Atmos Heal. 2015,8:265-272.

414 3. Jiang S. Dictionary of Traditional Chinese Crude Drugs .In: New Medical College (ed.) 415 .Shanghai Scientific Technologic, Shanghai; 1977.pg 2: 1636.

416 4. Fan C, Jin HZ, Wu L, Zhang Y, Ye RD, Zhang W, et al. An exploration of traditional 417 Chinese medicinal plants with anti-inflammatory activities. Evidence-based $418 \quad$ Complement Altern Med. 2017, 2017: 1231820.

419 5. Mimaki Y, Kanmoto T, Sashida Y, Nishino A, Satomi Y, Nishino H. Steroidal Saponins 420 from the Underground Parts of Chlorophytum comosum and their Inhibitory Activity 421 on Tumor Promoter Induced Phospholipid Metabolism of HELA cells. 422 Phytochemistry.1996, 41(5):1405-1410.

423 6. Matsushita H, Kuwabara H, Ishikawa S, Mochizuki M. Apoptosis Induced in Human 424 Cell Line by n- Butanol extract from Chlorophytum comosum roots, Journal of Health $425 \quad$ Science. 2005, 51(3):341-345. 
7. Lei Z, Huhman DV, Sumner LW. Mass spectrometry strategies in metabolomics. J. Biol. Chem. 2011, 286(29):25435-42.

8. Smith CA, O’Maille G, Want EJ, Qin C, Trauger SA, Brandon TR, et al. METLIN: A metabolite mass spectral database. Ther Drug Monit. 2005, 27(6):747-51.

9. Herald TJ, Gadgil P, Tilley M. High-throughput micro plate assays for screening 431 flavonoid content and DPPH-scavenging activity in sorghum bran and flour. J Sci Food Agric. 2012, 92(11):2326-31.

433 10. Bolanos -De- La Torre AAS, Henderson T, Nigam PS, Owusu-Apenten RK. A 434 universally calibrated microplate ferric reducing antioxidant power (FRAP) assay for 435 foods and applications to Manuka honey. Food Chem. 2015, 174:119-23.

436 11. Weber M, Steinle H, Golombek S, Hann L, Schlensak C, Wendel HP, et al. Blood437 Contacting Biomaterials: In Vitro Evaluation of the Hemocompatibility. Front Bioeng $438 \quad$ Biotechnol. 2018, 6:99.

439 12. Kim K, Kim TH, Ihn HJ, Kim JE, Choi JY, Shin HI, et al. Inhibitory effect of 440 purpurogallin on osteoclast differentiation in vitro through the downregulation of c-fos 441 and NFATC1. Int J Mol Sci. 2018, 19(2): 601.

442 13. Park SY, Park JH, Kim HS, Lee CY, Lee HJ, Kang KS, et al. Systems-level mechanisms 443 of action of Panax ginseng: a network pharmacological approach. J. Ginseng Res. 444 2018. 42(1): 98-106.

445 14. Wu YB, Ni ZY, Shi QW, Dong M, Kiyota H, Gu YC, et al. Constituents from salvia 446 species and their biological activities. Chem. Rev. 2012. 112(11):5967-6026.

447 15. Kupchan SM, Sweeny JG, Baxter RL, Zimmerly VA, Sickles BR, Murae T. Gnididin, 448 Gniditrin, and Gnidicin, Novel Potent Antileukemic Diterpenoid Esters from Gnidia 449 lamprantha. J. Am. Chem. Soc. 1976, 98:5719. 
450 16. Roth BD, Blankley J, Hoefle ML, Holmes A, Roark WH, Trivedi BK, et al. Inhibitors

451 of Acyl-CoA:Cholesterol Acyltransferase. 1. Identification and Structure-Activity 452 Relationships of a Novel Series of Fatty Acid Anilide Hypocholesterolemic Agents. J 453 Med Chem. 1992, 37(12):1810-22.

454 17. Thyagarajan A, Sahu RP. Potential Contributions of Antioxidants to Cancer Therapy: 455 Immunomodulation and Radiosensitization. Integr. Cancer Ther. 2018. (2):210-216.

456 18. Amin K, Dannenfelser RM. In vitro hemolysis: Guidance for the pharmaceutical 457 scientist. J Pharm Sci. 2006, 95(6):1173-6.

458 19. Katoch M, Kumar R, Pal S, Ahuja A. Identification of Chlorophytum species ( $C$. 459 borivilianum, C. arundinaceum, C. laxum, C. capense and C. comosum) using molecular 460 markers. Ind Crops Prod 2010,32:389-393.

461 20. Tan W, Lu J, Huang M, Li Y, Chen M, Wu G, et al. Anti-cancer natural products isolated 462 from chinese medicinal herbs. Chin. Med.2011,6:27.

463 21. Podolak I, Galanty A, Sobolewska D. Saponins as cytotoxic agents: A review. 464 Phytochem. Rev.2010,9(3):425-474.

465 22. Deore SL, Jajoo NB, Chittam KP, Deshmukh TA. Comparative Pharmacognostic, 466 Phytochemical and Biological evaluation between five Chlorophytum species. 467 Pharmacogn. J.2015, 7(5):317-325.

468 23. Foti MC. Antioxidant properties of phenols. J Pharm Pharmacol.2007, 469 59(12):1673-85.

470 24. Kumar N, Nidhi G. Phenolic acids: Natural versatile molecules with promising 471 therapeutic applications. Biotechnology Reports.2019, 24: e00370.

472 25. Xie X, Zu X, Liu F, Wang T, Wang X, Chen H, Liu K, Wang P, Liu F, Zheng Y, Bode 473 AM, Dong Z, Kim DJ. Purpurogallin is a novel mitogen-activated protein kinase kinase 
$474 \quad 1 / 2$ inhibitor that suppresses esophageal squamous cell carcinoma growth in vitro and in 475 vivo. Mol Carcinog. 2019, 58(7):1248-1259. 
Table 1 Identified chemical constituents and their \% content from leaves of Chlorophytum comosum by GC/MS

\begin{tabular}{|c|c|c|c|c|c|c|c|c|c|}
\hline $\begin{array}{l}\text { Peak } \\
\text { No. }\end{array}$ & $\begin{array}{l}\text { Identified Compound } \\
\text { Name (IUPAC) }\end{array}$ & Common Name & Compound Class & CAS No. & $\begin{array}{l}\text { Pub Chem } \\
\text { CID }\end{array}$ & $\begin{array}{l}\text { Molecular } \\
\text { Weight }\end{array}$ & $\begin{array}{l}\text { Molecular } \\
\text { Formula }\end{array}$ & $\begin{array}{l}\% \\
\text { area }\end{array}$ & $\begin{array}{l}\text { Retention } \\
\text { Time }\end{array}$ \\
\hline 1 & 1-methylpiperidine & N-Methylpiperidine & t-Amines & $626-67-5$ & 12291 & 99.177 & $\mathrm{C}_{6} \mathrm{H}_{13} \mathrm{~N}$ & 0.42 & 5.768 \\
\hline 2 & $\begin{array}{l}\text { 2-methyl-N-(2- } \\
\text { methylbutyl) butan-1- } \\
\text { imine }\end{array}$ & $\begin{array}{l}\text { 1-Butanamine, 2- } \\
\text { methyl-N-(2- } \\
\text { methylbutylidene)- }\end{array}$ & Aliphatic Imines & $54518-97-7$ & 521517 & 155.285 & $\mathrm{C}_{10} \mathrm{H}_{21} \mathrm{~N}$ & 0.79 & 7.840 \\
\hline 3 & $\begin{array}{l}\text { 3-methyl-N-(3- } \\
\text { methylbutyl)butan-1- } \\
\text { imine }\end{array}$ & $\begin{array}{l}\text { Isopentylidene } \\
\text { isopentylamine }\end{array}$ & Amines & $35448-31-8$ & 118823 & 155.285 & $\mathrm{C}_{10} \mathrm{H}_{21} \mathrm{~N}$ & 1.67 & 8.048 \\
\hline 4 & 2-methoxyphenol & Guaiacol & Phenols & $90-05-1$ & 460 & 124.139 & $\mathrm{C}_{7} \mathrm{H}_{8} \mathrm{O}_{2}$ & 1.38 & 9.021 \\
\hline 5 & Undecane & Undecane & $\begin{array}{l}\text { Alkane } \\
\text { Hydrocarbon }\end{array}$ & $1120-21-4$ & 14257 & 156.313 & $\mathrm{C}_{11} \mathrm{H}_{24}$ & 2.44 & 9.219 \\
\hline 6 & $\begin{array}{l}\text { butan-2-yloxy-butyl- } \\
\text { dimethylsilane }\end{array}$ & $\begin{array}{l}\text { 2butyl(dimethyl)silylo } \\
\text { xybutane }\end{array}$ & Organosilicon & NA & 582888 & 188.386 & $\mathrm{C}_{10} \mathrm{H}_{24} \mathrm{OSi}$ & 2.42 & 10.743 \\
\hline 7 & butoxy(trimethyl)silane & $\begin{array}{l}\text { 1-Butanol, } \\
\text { trimethylsilyl ether }\end{array}$ & Organosilicon & $1825-65-6$ & 519537 & 146.305 & $\mathrm{C}_{7} \mathrm{H}_{18} \mathrm{OSi}$ & 5.81 & 12.335 \\
\hline 8 & $\begin{array}{l}\text { 2-tert-butyl-5- } \\
\text { (hydroxymethyl)-5- } \\
\text { methyl-1,3-dioxolan-4- } \\
\text { one }\end{array}$ & $\begin{array}{l}\text { 2-t-Butyl-5- } \\
\text { hydroxymethyl-5- } \\
\text { methyl-[1,3]dioxolan- } \\
\text { 4-one }\end{array}$ & Oxalidinone & NA & 554337 & 188.223 & $\mathrm{C}_{9} \mathrm{H}_{16} \mathrm{O}_{4}$ & 41.05 & 12.895 \\
\hline 9 & $\begin{array}{l}\text { 4-ethenyl-2- } \\
\text { methoxyphenol }\end{array}$ & 4-vinylguaiacol & Phenols & $7786-61-0$ & 332 & 150.177 & $\mathrm{C}_{9} \mathrm{H}_{10} \mathrm{O}_{2}$ & 1.28 & 13.310 \\
\hline 10 & 2,6-dimethoxyphenol & Syringol & Phenols & $91-10-1$ & 7041 & 154.165 & $\mathrm{C}_{8} \mathrm{H}_{10} \mathrm{O}_{3}$ & 1.08 & 13.933 \\
\hline
\end{tabular}




\begin{tabular}{|c|c|c|c|c|c|c|c|c|c|}
\hline $\begin{array}{l}\text { Peak } \\
\text { No. }\end{array}$ & $\begin{array}{l}\text { Identified Compound } \\
\text { Name (IUPAC) }\end{array}$ & Common Name & Compound Class & CAS No. & $\begin{array}{l}\text { Pub Chem } \\
\text { CID }\end{array}$ & $\begin{array}{l}\text { Molecular } \\
\text { Weight }\end{array}$ & $\begin{array}{l}\text { Molecular } \\
\text { Formula }\end{array}$ & $\begin{array}{l}\% \\
\text { area }\end{array}$ & $\begin{array}{l}\text { Retention } \\
\text { Time }\end{array}$ \\
\hline 11 & 3-(hydroxymethyl)phenol & $\begin{array}{l}\text { 3-Hydroxybenzyl } \\
\text { alcohol }\end{array}$ & Phenols & $620-24-6$ & 102 & 124.139 & $\mathrm{C}_{7} \mathrm{H}_{8} \mathrm{O}_{2}$ & 7.59 & 14.582 \\
\hline 12 & dodecane-1-thiol & 1-dodecanethiol & Thiols & $112-55-0$ & 8195 & 202.4 & $\mathrm{C}_{12} \mathrm{H}_{26} \mathrm{~S}$ & 0.66 & 17.032 \\
\hline 13 & $\begin{array}{l}\text { 2-tert-butyl-4- } \\
\text { methoxyphenol }\end{array}$ & $\begin{array}{l}\text { (1,1Dimethylethyl)-4- } \\
\text { methoxyphenol }\end{array}$ & Aromatic Ether & $25013-16-5$ & 8456 & 180.247 & $\mathrm{C}_{11} \mathrm{H}_{16} \mathrm{O}_{2}$ & 1.68 & 17.332 \\
\hline 14 & $\begin{array}{l}\text { 2-cyclohepta-2,4,6-trien- } \\
\text { 1-yl-1H-pyrrole }\end{array}$ & $\begin{array}{l}\text { 2-cyclohepta-2,4,6- } \\
\text { trien-1-yl-1H-pyrrole }\end{array}$ & Pyrrole Alkaloids & NA & 593678 & 157.216 & $\mathrm{C}_{11} \mathrm{H}_{11} \mathrm{~N}$ & 0.66 & 17.646 \\
\hline 15 & $\begin{array}{l}\text { Cyclopenta[C]Pyran-1-ol, } \\
\text { 1,4a,5,6,7,7a-Hexahydro- } \\
\text { 4,7-Dimethyl acetate, [1S- } \\
\text { (1.Alpha.,4a.Alpha.,7.Beta } \\
\text {.,7a.alpha.) }\end{array}$ & $\begin{array}{l}\text { (1S)-1 } \\
\text { Acetooxymyodesert- } \\
\text { 3-ene }\end{array}$ & Unknown & NA & NA & 210 & $\mathrm{C}_{12} \mathrm{H}_{18} \mathrm{O}_{3}$ & 0.19 & 19.107 \\
\hline 16 & tetradecyl prop-2-enoate & $\begin{array}{l}\text { 2-Propenoic } \\
\text { acid,tetradecyl ester }\end{array}$ & Carboxyester & $21643-42-5$ & 88984 & 268.441 & $\mathrm{C}_{17} \mathrm{H}_{32} \mathrm{O}_{2}$ & 2.35 & 19.183 \\
\hline 17 & $\begin{array}{l}(2 \mathrm{R}, 5 \mathrm{~S}, 6 \mathrm{~S})-2,6,10,10- \\
\text { tetramethyl-1- } \\
\text { oxaspiro[4.5]decan-6-ol }\end{array}$ & $\begin{array}{l}\text { 2,6,10,10- } \\
\text { Tetramethyl-1- } \\
\text { oxaspiro[4.5]decan-6- } \\
\text { ol }\end{array}$ & Terpenoid & 77981-89-6 & 23624156 & 212.333 & $\mathrm{C}_{13} \mathrm{H}_{24} \mathrm{O}_{2}$ & 0.34 & 20.426 \\
\hline 18 & $\begin{array}{l}\text { 2,2-dimethyl-3-(2- } \\
\text { methylprop-1- } \\
\text { enyl)cyclopropane-1- } \\
\text { carboxylic acid }\end{array}$ & Chrysanthemic acid & $\begin{array}{l}\text { Cyclopropane } \\
\text { carboxylic acid }\end{array}$ & $10453-89-1$ & 2743 & 168.236 & $\mathrm{C}_{10} \mathrm{H}_{16} \mathrm{O}_{2}$ & 0.86 & 20.468 \\
\hline
\end{tabular}




\begin{tabular}{|c|c|c|c|c|c|c|c|c|c|}
\hline $\begin{array}{l}\text { Peak } \\
\text { No. }\end{array}$ & $\begin{array}{l}\text { Identified Compound } \\
\text { Name (IUPAC) }\end{array}$ & Common Name & Compound Class & CAS No. & $\begin{array}{l}\text { Pub Chem } \\
\text { CID }\end{array}$ & $\begin{array}{l}\text { Molecular } \\
\text { Weight }\end{array}$ & $\begin{array}{l}\text { Molecular } \\
\text { Formula }\end{array}$ & $\begin{array}{l}\% \\
\text { area }\end{array}$ & $\begin{array}{l}\text { Retention } \\
\text { Time }\end{array}$ \\
\hline 19 & $\begin{array}{l}\text { bis(2-methylpropyl) } \\
\text { benzene-1,2- } \\
\text { dicarboxylate }\end{array}$ & $\begin{array}{l}\text { Phthalic acid, } \\
\text { diisobutyl ester }\end{array}$ & phthalate ester & $84-69-5$ & 6782 & 278.348 & $\mathrm{C}_{16} \mathrm{H}_{22} \mathrm{O}_{4}$ & 0.4 & 21.447 \\
\hline 20 & $\begin{array}{l}\text { 6-methylhepta-1,6-dien- } \\
\text { 2-ylbenzene }\end{array}$ & $\begin{array}{l}\text { (5-Methyl-1- } \\
\text { methylene-5- } \\
\text { hexenyl)benzene }\end{array}$ & Unknown & NA & 576233 & 186.298 & $\mathrm{C}_{14} \mathrm{H}_{18}$ & 1.11 & 22.982 \\
\hline 21 & $\begin{array}{l}\text { 6-methylhepta-1,6-dien- } \\
\text { 2-ylbenzene }\end{array}$ & $\begin{array}{l}\text { (5-Methyl-1- } \\
\text { methylene-5- } \\
\text { hexenyl)benzene }\end{array}$ & Unknown & NA & 576233 & 186.298 & $\mathrm{C}_{14} \mathrm{H}_{18}$ & 1.71 & 23.018 \\
\hline 22 & $\begin{array}{l}\text { Trimethylsilyl } \\
\text { hexadecanoate }\end{array}$ & Palmitic acid, TMS & Fatty acid & $55520-89-3$ & 521638 & 328.612 & $\mathrm{C}_{19} \mathrm{H}_{40} \mathrm{O}_{2} \mathrm{Si}$ & 0.78 & 23.695 \\
\hline 23 & $\begin{array}{l}\text { 1-Methyl-5- } \\
\text { phenylbicyclo[3.2.0]Hepta } \\
\text { ne }\end{array}$ & $\begin{array}{l}\text { 1-Methyl-5- } \\
\text { phenylbicyclo[3.2.0] } \\
\text { Heptane }\end{array}$ & Unknown & NA & 576531 & 186.298 & $\mathrm{C}_{14} \mathrm{H}_{18}$ & 1.03 & 23.812 \\
\hline 24 & $\begin{array}{l}\text { 3-(2-phenylaziridin-1- } \\
\text { yl)propane nitrile }\end{array}$ & $\begin{array}{l}\text { 3-(2-Phenyl-1- } \\
\text { aziridinyl)propane } \\
\text { nitrile }\end{array}$ & Aziridine & NA & 563034 & 171.231 & $\mathrm{C}_{11} \mathrm{H}_{12} \mathrm{~N}_{2}$ & 0.76 & 24.115 \\
\hline 25 & $\begin{array}{l}\text { methyl (Z)-octadec-9- } \\
\text { enoate }\end{array}$ & Methyl Oleate & $\begin{array}{l}\text { Fatty acid methyl } \\
\text { ester }\end{array}$ & $112-62-9$ & 5364509 & 296.495 & $\mathrm{C}_{19} \mathrm{H}_{36} \mathrm{O}_{2}$ & 0.73 & 24.365 \\
\hline 26 & methyl octadecanoate & Methyl Sterate & $\begin{array}{l}\text { Fatty acid methyl } \\
\text { ester }\end{array}$ & $112-61-8$ & 8201 & 298.511 & $\mathrm{C}_{19} \mathrm{H}_{38} \mathrm{O}_{2}$ & 0.63 & 24.664 \\
\hline 27 & $\begin{array}{l}\text { ethyl (E)-3-(4- } \\
\text { methylphenyl)prop-2- } \\
\text { enoate }\end{array}$ & $\begin{array}{l}\text { Ethyl-4-methyl } \\
\text { cinnamate }\end{array}$ & $\begin{array}{l}\text { Methyl ester of } \\
\text { Cinnamic acid }\end{array}$ & 20511-20-0 & 641318 & 190.242 & $\mathrm{C}_{12} \mathrm{H}_{14} \mathrm{O}_{2}$ & 0.79 & 26.29 \\
\hline
\end{tabular}




\begin{tabular}{|c|c|c|c|c|c|c|c|c|c|}
\hline $\begin{array}{l}\text { Peak } \\
\text { No. }\end{array}$ & $\begin{array}{l}\text { Identified Compound } \\
\text { Name (IUPAC) }\end{array}$ & Common Name & Compound Class & CAS No. & $\begin{array}{l}\text { Pub Chem } \\
\text { CID }\end{array}$ & $\begin{array}{l}\text { Molecular } \\
\text { Weight }\end{array}$ & $\begin{array}{l}\text { Molecular } \\
\text { Formula }\end{array}$ & $\begin{array}{l}\% \\
\text { area }\end{array}$ & $\begin{array}{l}\text { Retention } \\
\text { Time }\end{array}$ \\
\hline 28 & $\begin{array}{l}\text { bis(2-ethylhexyl) } \\
\text { hexanedioate }\end{array}$ & DEHA & Diester & $103-23-1$ & 7641 & 370.574 & $\mathrm{C}_{22} \mathrm{H}_{42} \mathrm{O}_{4}$ & 4.08 & 27.558 \\
\hline 29 & $\begin{array}{l}\text { 5,5bis } \\
\text { (heptylsulfanyl)pentane- } \\
\text { 1,2,3-triol }\end{array}$ & $\begin{array}{l}\text { D-Ribose, 2-deoxy- } \\
\text { bis(thioheptyl)- } \\
\text { dithioacetal }\end{array}$ & Polysaccharides & NA & 575898 & 380.646 & $\mathrm{C}_{19} \mathrm{H}_{40} \mathrm{O}_{3} \mathrm{~S}_{2}$ & 3.24 & 28.931 \\
\hline 30 & $\begin{array}{l}\text { bis(2-ethylhexyl) } \\
\text { benzene-1,2- } \\
\text { dicarboxylate }\end{array}$ & $\begin{array}{l}\text { Bis(2- } \\
\text { ethylhexyl)phthalate }\end{array}$ & $\begin{array}{l}\text { Ester of phthalic } \\
\text { acid }\end{array}$ & $117-81-7$ & 8343 & 390.564 & $\mathrm{C}_{24} \mathrm{H}_{38} \mathrm{O}_{4}$ & 1.54 & 29.51 \\
\hline \multirow[t]{2}{*}{31} & $\begin{array}{l}\text { (3S,8S,9S,10R,13R,14S,17 } \\
\text { R)-17-[(2R,5R)-5-ethyl-6- } \\
\text { methylheptan-2-yl]- }\end{array}$ & & & & & & & & \\
\hline & $\begin{array}{l}\text { 10,13-dimethyl- } \\
\text { 2,3,4,7,8,9,11,12,14,15,16 } \\
\text {,17-dodecahydro-1H- } \\
\text { cyclopenta[a]phenanthre } \\
\text { n-3-ol }\end{array}$ & $\beta$-Sitosterol & Phytosterols & $83-46-5$ & 222284 & 414.718 & $\mathrm{C}_{29} \mathrm{H}_{50} \mathrm{O}$ & 1.24 & 38.051 \\
\hline 32 & $\begin{array}{l}\text { (E)-5-[(1S,2R,4aR,8aR)- } \\
\text { 1,2,4a,5-tetramethyl- } \\
\text { 2,3,4,7,8,8a- } \\
\text { hexahydronaphthalen-1- } \\
\text { yl]-3-methylpent-2-en-1- } \\
\text { ol }\end{array}$ & Kolavenol & Diterpenoids & $19941-83-4$ & 6442554 & 290.491 & $\mathrm{C}_{20} \mathrm{H}_{34} \mathrm{O}$ & 0.49 & 39.571 \\
\hline
\end{tabular}




\begin{tabular}{|c|c|c|c|c|c|c|c|c|c|}
\hline $\begin{array}{l}\text { Peak } \\
\text { No. }\end{array}$ & $\begin{array}{l}\text { Identified Compound } \\
\text { Name (IUPAC) }\end{array}$ & Common Name & Compound Class & CAS No. & $\begin{array}{l}\text { Pub Chem } \\
\text { CID }\end{array}$ & $\begin{array}{l}\text { Molecular } \\
\text { Weight }\end{array}$ & $\begin{array}{l}\text { Molecular } \\
\text { Formula }\end{array}$ & $\begin{array}{l}\% \\
\text { area }\end{array}$ & $\begin{array}{l}\text { Retention } \\
\text { Time }\end{array}$ \\
\hline 33 & $\begin{array}{l}(1 \mathrm{R}, 2 \mathrm{~S}, 4 \mathrm{~S}, 5 \text { 'S } \mathrm{S}, 6 \mathrm{R}, 7 \mathrm{~S}, 8 \mathrm{R}, 9 \mathrm{~S}, \\
12 \mathrm{~S}, 13 \mathrm{~S}, 16 \mathrm{~S}, 18 \mathrm{R})- \\
5 ', 7,9,13- \\
\text { tetramethylspiro[5- } \\
\text { oxapentacyclo[10.8.0.02,9 } \\
.04,8.013,18] \text { icosane-6,2'- } \\
\text { oxanel-16-ol }\end{array}$ & Sarsasapogenin & Steroids & $126-19-2$ & 92095 & 416.646 & $\mathrm{C}_{27} \mathrm{H}_{44} \mathrm{O}_{3}$ & 7.54 & 42.569 \\
\hline 34 & $\begin{array}{l}(1 S, 2 S, 4 S, 5 ' R, 6 R, 7 S, 8 R, 9 S, \\
12 S, 13 R, 16 S)-5 ', 7,9,13- \\
\text { tetramethylspiro[5- } \\
\text { oxapentacyclo[10.8.0.02,9 } \\
.04,8.013,18] \text { icos-18-ene- } \\
\text { 6,2'-oxane]-16-ol }\end{array}$ & Diosgenin & Sapogenins & $512-04-9$ & 99474 & 414.63 & $\mathrm{C}_{27} \mathrm{H}_{42} \mathrm{O}_{3}$ & 1.27 & 43.393 \\
\hline
\end{tabular}


485 Table 2 Identified chemical constituents and their \% content from roots of Chlorophytum comosum by GC/MS

\begin{tabular}{|c|c|c|c|c|c|c|c|c|c|}
\hline $\begin{array}{l}\text { Peak } \\
\text { No. }\end{array}$ & Identified Compound Name (IUPAC) & Common Name & Compound Class & CAS No. & $\begin{array}{l}\text { PubChem } \\
\text { CID }\end{array}$ & $\begin{array}{l}\text { Molecular } \\
\text { Weight }\end{array}$ & $\begin{array}{l}\text { Molecular } \\
\text { Formula }\end{array}$ & $\begin{array}{l}\% \\
\text { Area }\end{array}$ & $\begin{array}{l}\text { Retention } \\
\text { Time }\end{array}$ \\
\hline 1 & Dodecane & Dodecane & $\begin{array}{l}\text { Alkane } \\
\text { Hydrocarbon }\end{array}$ & $112-40-3$ & 8182 & 170.34 & $\mathrm{C}_{12} \mathrm{H}_{26}$ & 9.37 & 9.213 \\
\hline 2 & $\begin{array}{l}\text { 4a,8-dimethyl-2-prop-1-en-2-yl- } \\
\text { 2,3,4,5,6,7-hexahydro-1H-naphthalene }\end{array}$ & Naphthalene & $\begin{array}{l}\text { Aromatic } \\
\text { Hydrocarbon }\end{array}$ & $41071-31-2$ & 605019 & 204.357 & $\mathrm{C}_{15} \mathrm{H}_{24}$ & 0.64 & 14.949 \\
\hline 3 & Diethyl benzene-1,2-dicarboxylate & Diethyl phthalate & $\begin{array}{l}\text { Benzoic acid } \\
\text { esters }\end{array}$ & $84-66-2$ & 6781 & 222.24 & $\mathrm{C}_{12} \mathrm{H}_{14} \mathrm{O}_{4}$ & 2.29 & 17.725 \\
\hline 4 & 4-trimethylsilyloxycyclohexan-1-ol & $\begin{array}{l}\text { Cis -1,4- } \\
\text { cyclohexanediol,o- } \\
\text { (trimethylsilyl) }\end{array}$ & Fatty Alcohols & $54725-69-8$ & 554465 & 188.342 & $\mathrm{C}_{19} \mathrm{H}_{20} \mathrm{O}_{2} \mathrm{Si}$ & 1.94 & 18.672 \\
\hline 5 & $(3 \mathrm{E}, 5 \mathrm{E})$-2,6-dimethylocta-3,5-diene & $\begin{array}{l}\text { 2,7-dimethylocta- } \\
\text { 3,5-diene }\end{array}$ & Alkenes & $28980-73-6$ & 17939649 & 138.254 & $\mathrm{C}_{10} \mathrm{H}_{18}$ & 0.91 & 19.126 \\
\hline 6 & (6S) 6-methyloctan-1-ol & 6- Methyl-1-octanol & $\begin{array}{l}\text { Aliphatic } \\
\text { Hydroxy } \\
\text { Compound }\end{array}$ & $110453-78-6$ & 520908 & 144.258 & $\mathrm{C}_{9} \mathrm{H}_{20} \mathrm{O}$ & 0.77 & 19.206 \\
\hline 7 & Trimethylsilyl hexadecanoate & Palmitic acid & Fatty Acids & $55520-89-3$ & 521638 & 328.612 & $\mathrm{C}_{19} \mathrm{H}_{40} \mathrm{O}_{2} \mathrm{Si}$ & 2.98 & 23.705 \\
\hline 8 & Methyl 9,10-Dideutero-9-Octadecenoate & Methyl Elaidate & Fatty Acids & $1937-62-8$ & 5280590 & 298.00 & $\mathrm{C}_{19} \mathrm{H}_{34} \mathrm{D}_{2} \mathrm{O}_{2}$ & 2.95 & 24.371 \\
\hline
\end{tabular}




\begin{tabular}{|c|c|c|c|c|c|c|c|c|c|}
\hline 9 & Methyl 15-methylhexadecanoate & $\begin{array}{l}\text { Hexadecanoic acid, } \\
\text { 15-methyl-,methyl } \\
\text { ester }\end{array}$ & Fatty Acids & $6929-04-0$ & 522345 & 284.484 & $\mathrm{C}_{18} \mathrm{H}_{36} \mathrm{O}_{2}$ & 2.95 & 24.669 \\
\hline 10 & bis(2-ethylhexyl) hexanedioate & $\begin{array}{l}\text { Diethylhexyl } \\
\text { adiapate }\end{array}$ & Esters & $103-23-1$ & 7641 & 370.574 & $\mathrm{C}_{22} \mathrm{H}_{42} \mathrm{O}_{4}$ & 18.9 & 27.56 \\
\hline 11 & $\begin{array}{l}\mathrm{N}-[4-(2-\text { tert-butyl-5-oxo-1,3-dioxolan-4- } \\
\text { yl)butyl]formamide }\end{array}$ & Formamide & Amide & NA & 582477 & 243.303 & $\mathrm{C}_{12} \mathrm{H}_{21} \mathrm{NO}_{4}$ & 1.35 & 28.651 \\
\hline 12 & $\begin{array}{l}\text { bis(2-ethylhexyl) benzene-1,2- } \\
\text { dicarboxylate }\end{array}$ & $\begin{array}{l}\text { Bis(2-ethylhexyl) } \\
\text { phthalate }\end{array}$ & Esters & $117-81-7$ & 8343 & 390.564 & $\mathrm{C}_{24} \mathrm{H}_{38} \mathrm{O}_{4}$ & 7.35 & 29.514 \\
\hline 13 & Sarsasapogenin 3-tosylate & Tigogenin tosylate & $\begin{array}{l}\text { Steroidal } \\
\text { Glycoside }\end{array}$ & NA & 587000 & 570.829 & $\mathrm{C}_{34} \mathrm{H}_{50} \mathrm{O}_{5} \mathrm{~S}$ & 4.43 & 36.693 \\
\hline 14 & $\begin{array}{l}\text { (3S,8S,9S,10R,13R,14S,17R)-17-[(2R,5R)- } \\
\text { 5-ethyl-6-methylheptan-2-yl]-10,13- } \\
\text { dimethyl-2,3,4,7,8,9,11,12,14,15,16,17- } \\
\text { dodecahydro-1H- } \\
\text { cyclopenta[a]phenanthren-3-ol }\end{array}$ & $\beta$-Sitosterol & Phytosterols & $83-46-5$ & 222284 & 414.718 & $\mathrm{C}_{29} \mathrm{H}_{50} \mathrm{O}$ & 7.79 & 38.062 \\
\hline 15 & $\begin{array}{l}\text { 2,2,4a,7a-Tetramethyl-1,2a,3,4,5,6,7,7b- } \\
\text { octahydrocyclobuta[e]inden-5-ol }\end{array}$ & $\begin{array}{l}\text { 2,2,4a,7a- } \\
\text { Tetramethyldecahy } \\
\text { dro- } 1 \mathrm{H}- \\
\text { cyclobuta[e]inden- } \\
\text { 5-ol }\end{array}$ & Sesquiterpenes & NA & 573804 & 222.372 & $\mathrm{C}_{15} \mathrm{H}_{26} \mathrm{O}$ & 4.97 & 39.568 \\
\hline 16 & Neotigogenin & 25S-Tigogenin & Triterpenoids & $470-01-9$ & 12304433 & 416.646 & $\mathrm{C}_{27} \mathrm{H}_{44} \mathrm{O}_{3}$ & 16.2 & 42.566 \\
\hline 17 & $\begin{array}{l}\left(1 \mathrm{R}, 2 \mathrm{~S}, 4 \mathrm{~S}, 5^{\prime} \mathrm{R}, 6 \mathrm{R}, 7 \mathrm{~S}, 8 \mathrm{R}, 9 \mathrm{~S}, 12 \mathrm{~S}, 13 \mathrm{~S}, 18 \mathrm{~S}\right) \text { - } \\
5^{\prime}, 7,9,13 \text {-tetramethylspiro[5 } \\
\text { oxapentacyclo[10.8.0.02,9.04,8.013,18]ic } \\
\text { osane-6,2'-oxane]-16-one }\end{array}$ & Yuccagenone & $\begin{array}{l}\text { Steroidal } \\
\text { Glycoside }\end{array}$ & $470-07-5$ & 101692 & 414.63 & $\mathrm{C}_{27} \mathrm{H}_{42} \mathrm{O}_{3}$ & 14.0 & 43.376 \\
\hline
\end{tabular}

486 NA: Not Available, Database - Wiley 8. Lib. / NIST14.1

487 Table 3 Tentatively identified metabolites in roots of Chlorophytum comosum by LC-ESI-MS (+ ion mode) 


\begin{tabular}{|c|c|c|c|c|c|c|}
\hline $\begin{array}{l}488 \\
489\end{array}$ & $\begin{array}{l}\text { Analyte } \\
\text { No. }\end{array}$ & $\begin{array}{l}\text { Tentative allotment of compounds based on } \\
\text { METLIN }\end{array}$ & $\begin{array}{l}\text { Parent ion } \\
(\mathrm{m} / \mathrm{z})\end{array}$ & Peak Intensity & $\begin{array}{l}\text { Mass Recorded } \\
\text { (METLIN) }\end{array}$ & METLIN ID \\
\hline $\begin{array}{l}490 \\
491\end{array}$ & 1. & 5,6-Dichloro-1,3-cyclohexadiene & 148.99 & $6.263 \mathrm{e} 6$ & 147.98 & 69011 \\
\hline 492 & 2. & 5-Fluoroindole-2-Carboxylic Acid & 180.04 & $4.115 \mathrm{e} 6$ & 179.03 & 44300 \\
\hline $\begin{array}{l}493 \\
494\end{array}$ & 3. & 4,5-Dichloro-3H-1,3-dithiol-2-one & 186.88 & $2.011 \mathrm{e} 6$ & 185.87 & 89030 \\
\hline $\begin{array}{l}495 \\
496\end{array}$ & 4. & Purpurogallin & 221.04 & $1.375 \mathrm{e} 6$ & 220.03 & 43934 \\
\hline 497 & 5. & Ginsenoyne B & 295.14 & $8.843 \mathrm{e} 5$ & 294.13 & 93731 \\
\hline $\begin{array}{l}498 \\
499\end{array}$ & 6. & Salicylic acid beta-D-glucoside & 301.09 & $5.089 \mathrm{e} 6$ & 300.08 & 95685 \\
\hline $\begin{array}{l}500 \\
501\end{array}$ & 7. & gamma-Glutamyl-beta-(isoxazolin-5-on-2- & 302.09 & $9.296 \mathrm{e} 5$ & 301.09 & 95006 \\
\hline $\begin{array}{l}502 \\
503\end{array}$ & 8. & 11beta-Chloromethylestradiol & 321.16 & $7.740 \mathrm{e} 5$ & 320.15 & 69957 \\
\hline $\begin{array}{l}504 \\
505\end{array}$ & 9. & Heneicosanedioic acid & 357.30 & $1.749 \mathrm{e} 6$ & 356.29 & 35988 \\
\hline $\begin{array}{l}506 \\
507\end{array}$ & 10. & Oleyl Anilide & 358.31 & $4.706 \mathrm{e} 6$ & 357.30 & 44935 \\
\hline 508 & 11. & Hexadecyl Acetyl Glycerol & 359.31 & $1.121 \mathrm{e} 6$ & 358.30 & 43452 \\
\hline $\begin{array}{l}509 \\
510\end{array}$ & 12. & 6-Bromo-5E,9Z,13Z-docosatrienoic acid & 413.20 & $1.289 \mathrm{e} 7$ & 412.19 & 96831 \\
\hline $\begin{array}{l}511 \\
512 \\
513 \\
514\end{array}$ & 13. & $\begin{array}{l}\text { 7,8,8',4'-Tetramethoxy-6 } \\
6 \text { "-dimethylpyrano } \\
{\left[2^{\prime \prime}, 3^{\prime \prime}: 5,6\right] \text { flavone }}\end{array}$ & 425.15 & $2.830 \mathrm{e} 6$ & 424.15 & 49820 \\
\hline 515 & 14. & Isosyringinoside & 535.20 & $7.687 \mathrm{e} 5$ & 534.19 & 95276 \\
\hline & 15. & Sagecoumarin & 537.09 & $1.345 \mathrm{e} 6$ & 536.09 & 89672 \\
\hline 517 & 16. & $\begin{array}{l}\text { 4-(4-Hydroxyphenyl)- } \\
\text { 2-butanone O- } \\
\text { [2-galloyl-6-p-coumaroylglucoside] }\end{array}$ & 625.18 & $1.132 \mathrm{e} 6$ & 624.18 & 93899 \\
\hline 518 & 17 & Gnidicin & 629.23 & $8.064 \mathrm{e} 5$ & 628.23 & 67423 \\
\hline
\end{tabular}


519 Table 4 Tentatively identified metabolites in leaves of Chlorophytum comosum by LC-ESI-MS (+ ion mode)

\begin{tabular}{|c|c|c|c|c|c|c|}
\hline $\begin{array}{l}\text { Analyte } \\
\text { No. }\end{array}$ & $\begin{array}{l}\text { Tentative allotment of } \\
\text { compounds based on METLIN }\end{array}$ & $\begin{array}{l}\text { Parent ion }(\mathrm{m} / \mathrm{z}) \\
\text { Positive ion mode } \\
{[\mathrm{M}+\mathrm{H}]}\end{array}$ & Peak Intensity & $\begin{array}{l}\text { Mass Recorded } \\
\text { (METLIN) }\end{array}$ & METLIN ID & 521 \\
\hline 1. & $\begin{array}{l}\text { 5,6-Dichloro-1,3- } \\
\text { cyclohexadiene }\end{array}$ & 148.9924 & 7.904e6 & 147.98 & 69011 & 522 \\
\hline 2. & Serratanidine & 296.1872 & $2.612 \mathrm{e} 6$ & 295.1784 & 67995 & 523 \\
\hline 3. & Salicylic acid beta-D-glucoside & 301.0908 & $6.044 \mathrm{e} 6$ & 300.0845 & 95685 & 524 \\
\hline 4. & $\begin{array}{l}\text { 3-(2-Heptenyloxy)-2- } \\
\text { hydroxypropyl undecanoate }\end{array}$ & 357.2993 & $2.186 \mathrm{e} 6$ & 356.2927 & 89668 & $\begin{array}{l}525 \\
526\end{array}$ \\
\hline 5. & Oleyl Anilide & 358.3117 & $6.640 \mathrm{e} 6$ & 357.3032 & 44935 & 527 \\
\hline 6. & $\begin{array}{l}\text { Methyl (9Z)-6'-oxo-6,5'-diapo- } \\
\text { 6-carotenoate }\end{array}$ & 393.2399 & $4.100 \mathrm{e} 6$ & 392.2351 & 88088 & 528 \\
\hline 7. & $\begin{array}{l}\text { 6-Bromo-5E,9Z,13Z- } \\
\text { docosatrienoic acid }\end{array}$ & 413.2067 & $4.100 \mathrm{e} 6$ & 412.1977 & 96831 & 529 \\
\hline
\end{tabular}




\begin{tabular}{|c|c|c|c|}
\hline Samples & Treatment & \multicolumn{2}{|c|}{ \% Haemolysis 537} \\
\hline Control & PBS & 0.00 & 538 \\
\hline Positive control & $1 \%$ SDS & 85.75 & \\
\hline \multirow{6}{*}{ CCLE } & 10 & 3.25 & \multirow{4}{*}{$\begin{array}{l}539 \\
540 \\
541 \\
542\end{array}$} \\
\hline & 20 & 5.30 & \\
\hline & 40 & 9.11 & \\
\hline & 80 & 17.18 & \\
\hline & 160 & 19.08 & 543 \\
\hline & 320 & 28.11 & \\
\hline & & & 544 \\
\hline & 10 & 3.40 & \\
\hline & 20 & 7.52 & 545 \\
\hline CCPF & 40 & 14.01 & \\
\hline CCNE & 80 & 19.24 & \\
\hline & 160 & 24.94 & \\
\hline & 320 & 30.01 & \\
\hline
\end{tabular}


Figure 1 Total ion chromatogram of Chlorophytum comosum aqueous root (a) and leaf extract (b) by LCESI- MS.

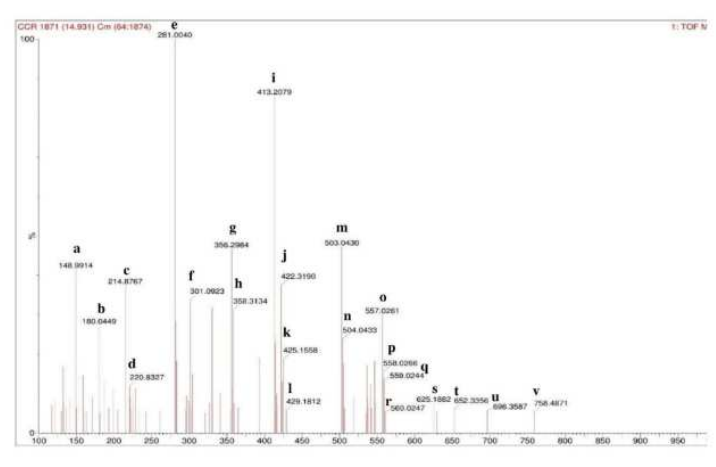

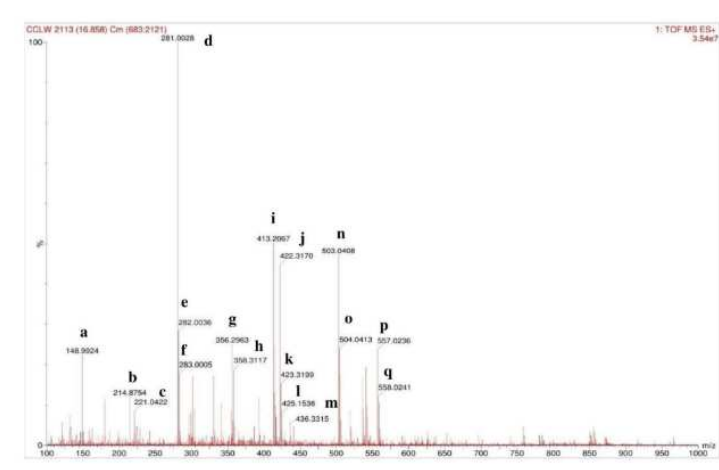

549

550 Selected peaks in roots were identified as (d) Purpurogallin, (f) Salicylic acid beta-D-glucoside, (g) Heneicosanedioic acid, (h) Oleyl Anilide and in

551 leaf as (a) 5,6-Dichloro-1,3-cyclohexadiene , (h) Oleyl Anilide (i) 6-Bromo-5E,9Z,13Z-docosatrienoic acid when compared with XCMS Metlin

552 database in positive ion mode. Note: At some peaks no metabolites were recorded in database.

Figure 2 Measurement of antioxidant potential of Chlorophytum comosum by DPPH, FRAP and TPC assays 

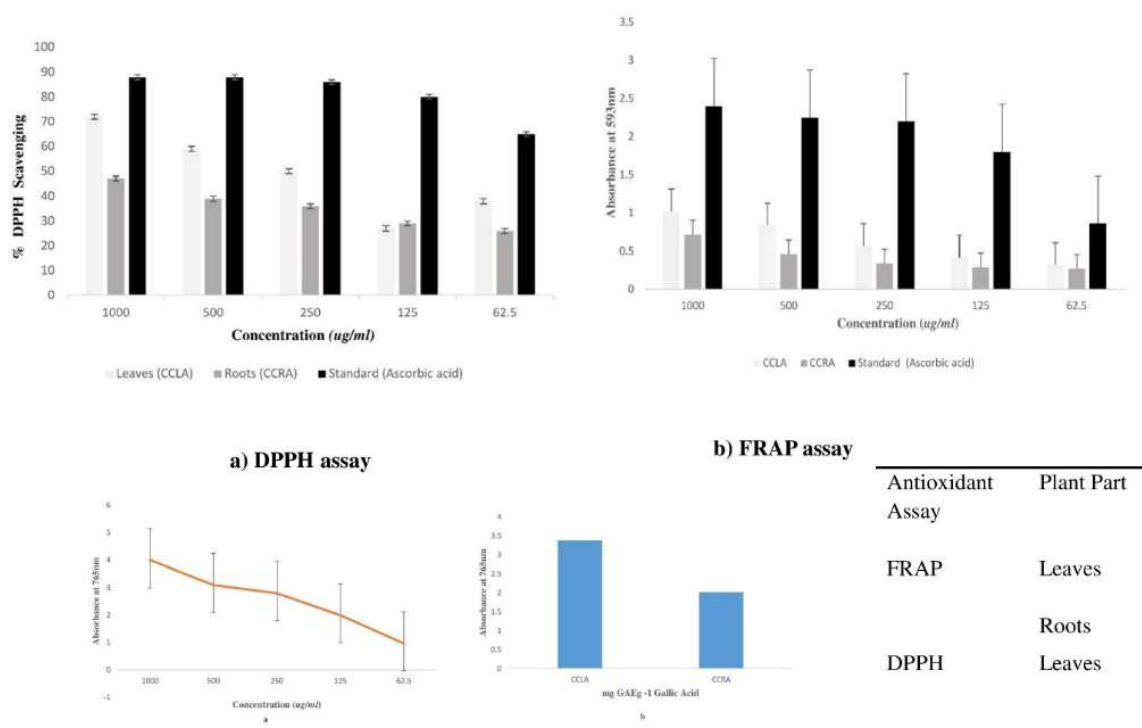

b) FRAP assa

\begin{tabular}{lllll}
\hline $\begin{array}{l}\text { Antioxidant } \\
\text { Assay }\end{array}$ & Plant Part & $\begin{array}{l}\text { Correlation } \\
\text { Coefficient } \\
\left(\mathrm{R}^{2}\right)\end{array}$ & P Value & $\begin{array}{l}\mathrm{IC}_{50} \\
\mathrm{ug} / \mathrm{ml}\end{array}$ \\
FRAP & Leaves & 0.97 & 0.0095 & 311.2 \\
& Roots & 0.83 & 0.0312 & 548.3 \\
DPPH & Leaves & 0.80 & 0.0310 & 3.08 \\
& Roots & 0.97 & 0.010 & 5.8 \\
& & & & \\
\hline
\end{tabular}

(a) Dose dependent \% scavenging of DPPH by aqueous leaf (CCLA) and roots (CCRA) extract of Chlorophytum comosum. (b) Total reducing 
Figure 3 MTT cell viability assay.

570

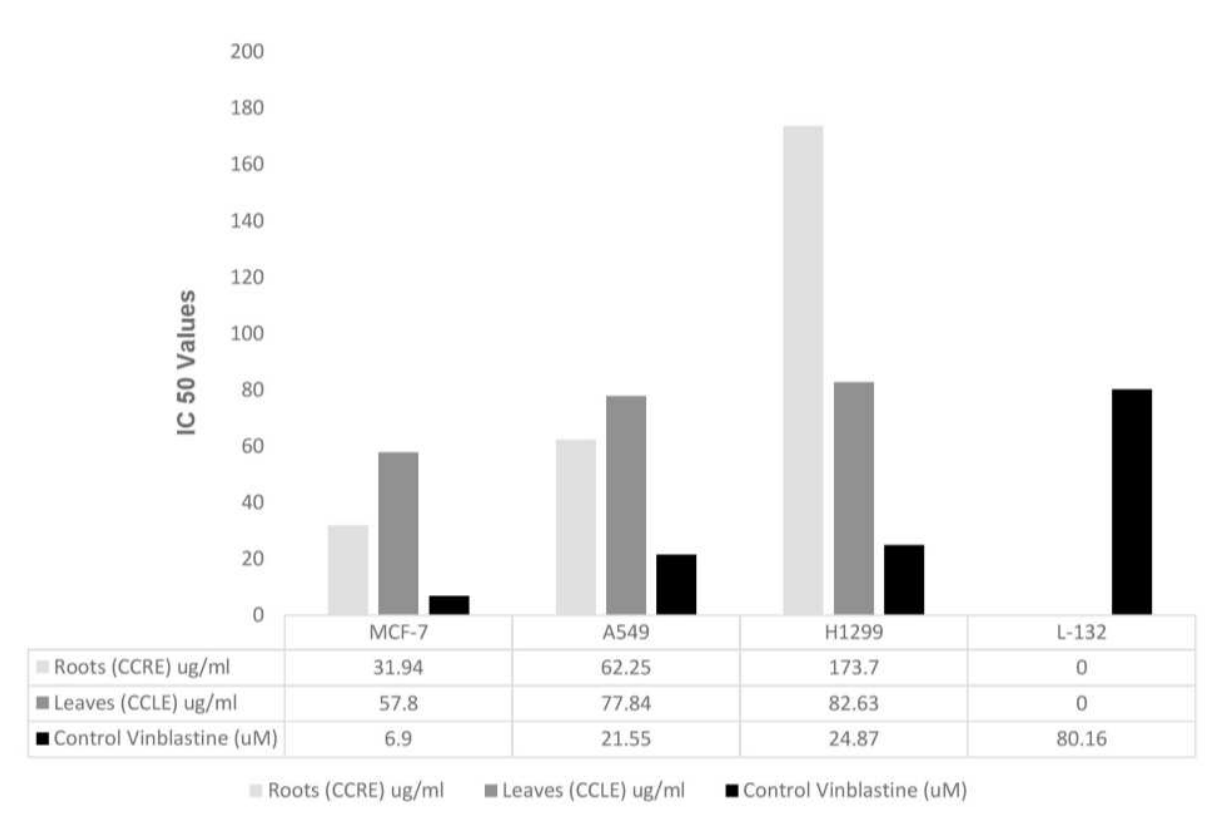

Antiproliferative activity of ethanolic roots and leaf extract were evaluated in a dose dependent exposure $(10 \mu \mathrm{g} / \mathrm{ml}-320 \mu \mathrm{g} / \mathrm{ml})$ of test samples for 574 24hrs. Vinblastine was used as control Dose dependent cell growth inhibitory effects of CCLE and CCRE on different cell lines and response of 
575 standard vinblastine on cancer versus normal cell line L-132 is represented with their respective IC50 values. In L-132 IC50 values were not 576 calculated for CCLE and CCRE due to lesser percentage inhibition $(<50 \%)$. The data is statistically significant with P $<0.05$. 


\section{Figures}

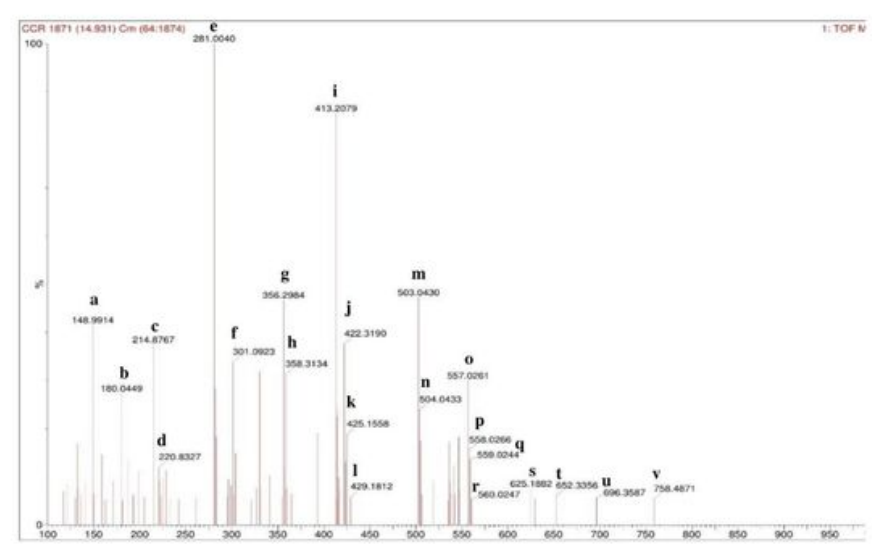

a

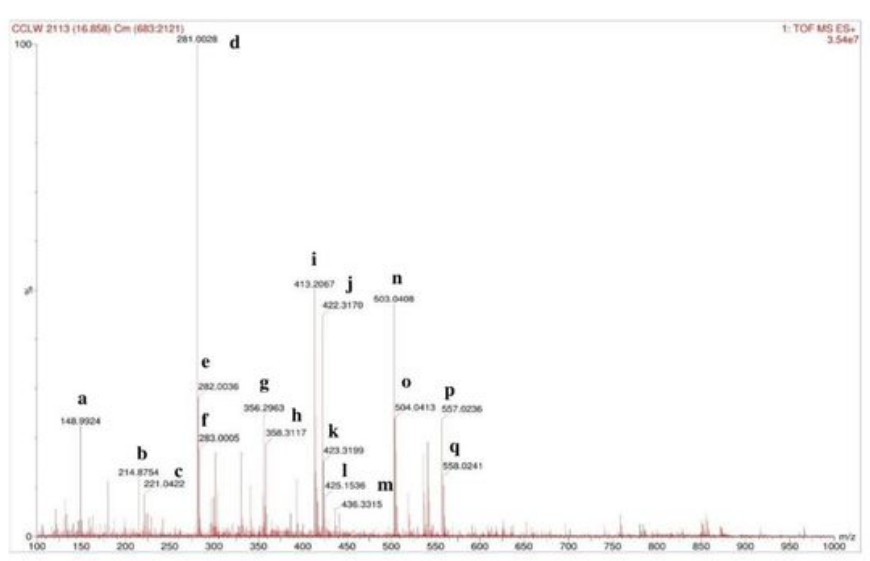

b

\section{Figure 1}

Total ion chromatogram of Chlorophytum comosum aqueous root (a) and leaf extract (b) by LCESI- MS. Selected peaks in roots were identified as (d) Purpurogallin, (f) Salicylic acid beta-D-glucoside, (g) Heneicosanedioic acid, (h) Oleyl Anilide and in leaf as (a) 5,6-Dichloro-1,3-cyclohexadiene , (h) Oleyl Anilide (i) 6-Bromo-5E,9Z,13Z-docosatrienoic acid when compared with XCMS Metlin database in positive ion mode. Note: At some peaks no metabolites were recorded in database. 


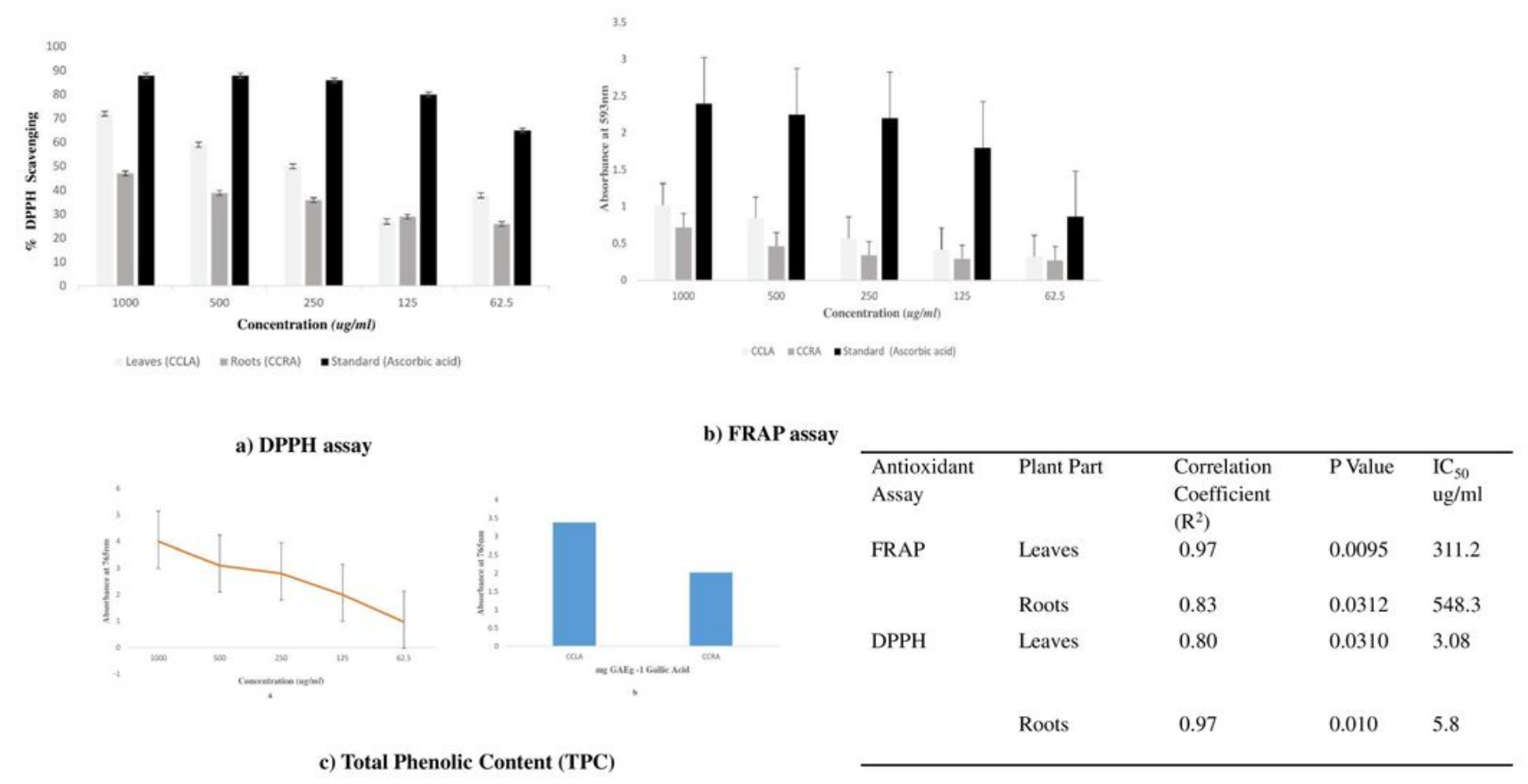

\section{Figure 2}

Measurement of antioxidant potential of Chlorophytum comosum by DPPH, FRAP and TPC assays (a) Dose dependent \% scavenging of DPPH by aqueous leaf (CCLA) and roots (CCRA) extract of Chlorophytum comosum. (b) Total reducing capacity of leaf and roots of Chlorophytum comosum as observed with dose dependent decrease in absorbance by FRAP assay. The values are mean \pm SD of three independent experiments with a correlation coefficient $(R 2=0.9921)$ and $p$ value $<0.05$. (c) Total phenolic content available in different parts of Chlorophytum comosum. (c-a) standard curve of gallic acid, (c-b) \% phenolic content in roots and leaves of $C$. comosum Total phenolic content was expressed as mg gallic acid equivalent (GAE) per gram of dried sample. 


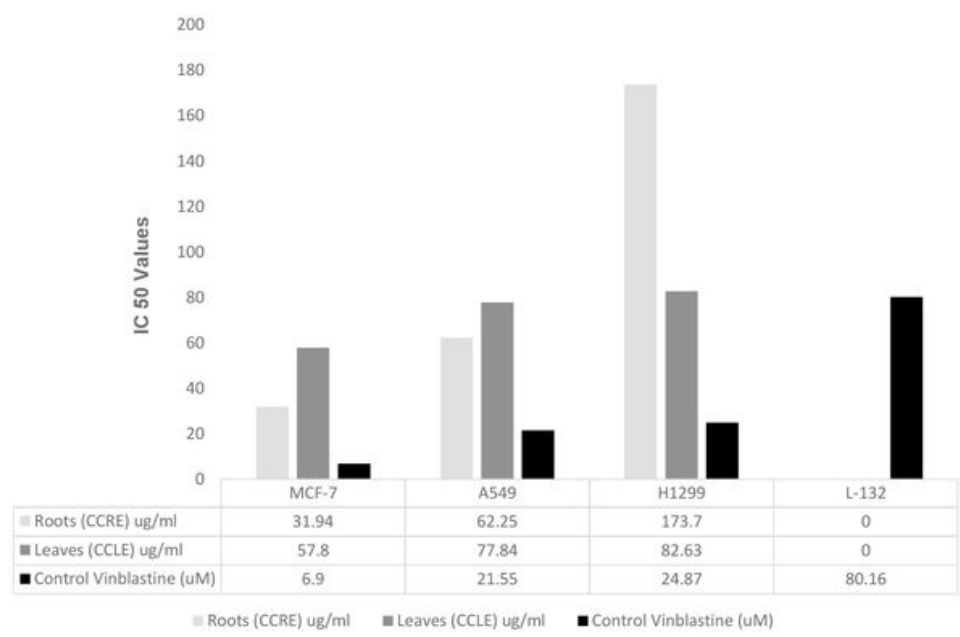

\section{Figure 3}

MTT cell viability assay. Antiproliferative activity of ethanolic roots and leaf extract were evaluated in a dose dependent exposure $(10 \mu \mathrm{g} / \mathrm{ml}-320 \mu \mathrm{g} / \mathrm{ml})$ of test samples for $24 \mathrm{hrs}$. Vinblastine was used as control Dose dependent cell growth inhibitory effects of CCLE and CCRE on different cell lines and response of standard vinblastine on cancer versus normal cell line L-132 is represented with their respective IC50 values. In L-132 IC50 values were not 575 calculated for CCLE and CCRE due to lesser percentage inhibition ( $<50 \%)$. The data is statistically significant with $\mathrm{P}<0.05$.

\section{Supplementary Files}

This is a list of supplementary files associated with this preprint. Click to download.

- Table1AdhamietaIGCMSANALYSISOFLEAVESOFCC.docx

- Table3AdhamietalLCESIMSROOTSCC.docx

- Table2AdhamietaIGCMSANALYSISOFROOTSOFCC.docx

- Table4AdhamietalLCESIMSLEAVESCC.docx

- Table5AdhamietalHaemolysisbyCC.docx 